\section{Anna Kuśmirek}

UKSW, Warszawa

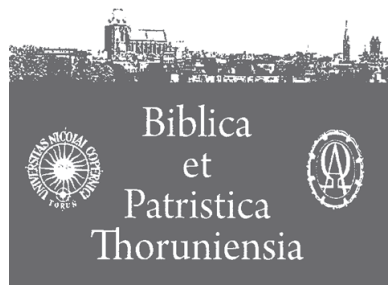

2 (2009)

\title{
Aramejska wersja Księgi Jonasza
}

Aramejska wersja Księgi Jonasza stanowi część Targumu do Proroków, przypisywanego Jonatanowi bez Uzziel, wybitnemu uczniowi Hillela Starszego (Megilla $3 a, \mathrm{~TB})^{1}$. Mimo że Targum Jonatana jest odpowiednikiem Targumu Onkelosa do Pięcioksięgu i został przyjęty jako oficjalny targum babiloński do drugiego zbioru ksiąg kanonu żydowskiego, czyli proroków (nebiim)2 , jest pochodzenia palestyńskiego i został napisany zasadniczo w aramejskim języku palestyńskim³ Obecne targumy powstały w rezultacie długiego i skomplikowanego procesu. W okresie II świątyni w Palestynie obok hebrajskiego był rozpowszechniony aramejski ${ }^{4}$. Zburzenie świątyni i dewastacja Judei oraz ostateczna klęska powstania Bar Kochby (132-135 po Chr.) przyczyniły się do zmniejszenia populacji, która posługiwała się językiem hebrajskim, a jego stosowanie ograniczyło się do wąskiego kręgu uczonych i skrybów.

1 Prawdziwi autorzy Targumu do Proroków są nieznani. Zob. np. P.S. Alexander, Jewish Aramaic Translations of Hebrew Scriptures, w: Mikra. Text, Translation, Reading \& Interpretation of the Hebrew Bible in Ancient Judaism \& Early Christianity, red. M.J. Mulder, Assen-Philadelphia 1988, s. 223.

2 Obejmuje księgi proroków wcześniejszych (Joz, Sdz, 1-2 Sm i 1-2 Krl) i proroków późniejszych (Iz, Jr, Ez i dwunastu proroków)

3 E. Levine podkreśla, że jest to utwór wczesnopalestyński, który reprezentuje najwcześniejszy etap rozwoju gatunku literackiego zw. midraszem. Wymienia przy tym trzy elementy związane z powstaniem tego zbioru: 1) aramejska wersja proroków zyskała kształt spółgłoskowy w Palestynie - stamtąd też pochodziła, a nie z Babilonii; 2) dzieło to powstało dość wcześnie, dlatego należy je traktować jako źródło, a nie jako pochodną najwcześniejszej literatury midraszowej, jaka zachowała się do naszych czasów; 3) dzieło to ma wymiar ezoteryczny i egzoteryczny, więc nie należy go uważać za przekład literalny. E. Levine, The Aramaic Version of Jonah, New York 1981, s. 7.

4 W okresie powygnaniowym doszło do zaniku znajomości i stosowania języka hebrajskiego zarówno wśród Żydów mieszkających w Palestynie, jak i w diasporze. W Babilonii żydowscy wygnańcy przyswoili sobie aramejski, a w Egipcie w publicznej recytacji Biblii hebrajski zastąpiła greka. Aramejskie papirusy z Elefantyny (ok. 450 przed Chr.), aramejskie fragmenty Ezd (300 przed Chr.) i Dn (ok. 165 przed Chr.) oraz wstawki aramejskie w późnych tekstach biblijnych świadczą o schyłku hebrajskiego już na tak wczesnym etapie. J. Fitzmyer, The Languages of Palestine in the First Century A.D., CBQ 32 (1970), s. 530nn. 
W tej sytuacji powstała potrzeba przekładu aramejskiego związanego z publicznym odczytywaniem Biblii hebrajskiej, które miało za cel przekazywanie sensu Pisma w nowych warunkach. Najpierw przekłady na język aramejski były przekazywane drogą ustną i od czasu do czasu podlegały pewnym modyfikacjom. Wszelkie takie zmiany sankcjonowały autorytety rabinackie, które czuwały nad przebiegiem nabożeństw w synagogach, łącznie z czytaniem fragmentów Tory i Proroków i ich tłumaczeniem. Targum zawierał zatem interpretację odpowiadającą ewoluującej Torze ustnej, często nawiązującą do homilii łączonych $\mathrm{z}$ danym czytaniem $^{5}$.

Martin McNamara przyjmuje, że datowanie kompozycji Targumu Jonatana przypadało pierwotnie na okres przed 135 r. po Chr., choć jest sprawą dyskusyjną, czy przed, czy też po 70 r. po Chr.; następnie datacja ta doczekała się rewizjí'. Obecnie przekazuje go ponad 20 rękopisów. Wprawdzie nie da się ustalić daty najwcześniejszej spisanej po aramejsku wersji Jonasza ${ }^{7}$, jednak oprócz fragmentów targumicznych odkrytych w Qumran sama Miszna mówi o pewnych fragmentach biblijnych „spisanych w postaci targumu”, a tradycja tannaicka wspomina o jakimś aramejskim tłumaczeniu, które istniało w I w. po Chr. ${ }^{8}$

Popularność Jonasza i istotne miejsce tej księgi w liturgii starożytnej każą się domyślać, że także targum musiał powstać na dość wczesnym etapie. Niewielki tekst Targumu Jonasza (48 wersów) pozwala prześledzić dokładnie interpretację biblijnej księgi'.

5 P.S. Alexander, The Targumim and the Rabbinic Rules for the Delivery of the Targum, w: Congress Volume Salamanca 1983, Suppl., VT 36, Leiden 1984, s. 14-20.

6 M. McNamara, Interpretation of Scripture in the Targumim, w: A History of the Biblical Interpretation, t. 1: The Ancient Period, red. A.J. Hauser, D.F. Watson, Grand Rapids, Michigan 2003, s. 168. S.H. Levey wskazuje, że miało to miejsce między III a V w. na terenie Babilonii. Zob. S.H. Levey, The Date of Targum Jonathan to the Prophets, VT 21 (1971), s. 186-196. Z metodą zastosowaną przy datowaniu targumów przez M. McNamara nie zgadza się np. A.D. York, The Dating of Targumic Literature, JSJ 5 (1974), s. 61-62.

7 W literaturze rabinackiej nie znajdziemy choćby najmniejszej wzmianki ani o spisaniu, ani o odczytywaniu aramejskiej wersji Jonasza. E. Levine, The Aramaic Version of Jonah, s. 7.

8 Zob. Miszna, Jadajim 4,5; TB Szabat 115A, Tosefta, Szabat 14; TJ Szabat 15c.

9 Wydania tekstu aramejskiego zob. A. Sperber, The Bible in Aramaic, wyd. 3, Leiden-Boston 2004; tekst aramejski Targumu Jonasza jest dostępny także w bazie elektronicznej: Comprehensive Aramaic Lexicon, S.A. Kaufman (red.), na http://call.cn.huc.edu/, dostęp 22.05.2009. Tekst aramejski i tłum. aram. Wraz z komentarzem zob. E. Levine, The Aramaic Version of Jonah, s. 37-98; tłum. ang. K.J. Cathcart, R.P. Gordon, The Targum of the Minor Prophets, AB 14, Edinburgh 1989, s. 105-109. 


\section{Księga Jonasza w tradycji żydowskiej}

W tradycji żydowskiej została rozwinięta dydaktyczna funkcja Księgi Jonasza. Już w starożytnej Palestynie księga ta miała uczyć, że Boże przebaczenie rozciąga się na wszystkich, którzy odwracają się od zła. Odczytywano ją w czasie publicznych postów, nałożonych na wspólnotę $\mathrm{w}$ okresie przedłużającej się suszy, zagrażającego ataku, trzęsienia ziemi, zarazy i innych niebezpieczeństw dla wspólnoty, które uważano za karę za nieprzestrzeganie Bożego słowa (zob. TB Rosz Haszana 16B). Wykroczenia te obejmowały zuchwalstwo, oszczerstwo, zaniedbywanie składania ofiar w świątyni, zaniechanie studiowania Tory itp. (por. TB Taanit 7B) ${ }^{10}$.

W Misznie można odnaleźć informacje o postach wspólnotowych i o centralnym miejscu Jonasza w homiletyce tamtego okresu, kiedy to księga miała budzić poczucie winy oraz skłaniać do skruchy i zmiany postępowania, aby w ten sposób uśmierzyć gniew Boga: „Oto rozporządzenie dotyczące sprawowania liturgii w dni postne: Arkę należy przenieść na plac miasta. Popiołem ze spalonego drewna należy posypać Arkę, głowę Nasi i głowę Ab Bet Din. Wszyscy pozostali też mają głowy posypać popiołem. Starszy spośród nich ma zwrócić się do nich ze słowem napomnienia: "Bracia, Pismo nie mówi o mieszkańcach Niniwy: Bóg zaś wejrzał na ich włosiennice i posty, lecz mówi: Bóg zaś wejrzał na ich uczynki, iż odwrócili się od złego postępowania (Jon 3,10)»” (Miszna, Taanit II, 1) ${ }^{11}$.

Obok recytacji Księgi Jonasza rozwijano także dość szeroko wątek prawości serca pokutujących Niniwitów, stawiając ich za przykład autentycznej skruchy godnej naśladowania. Rytualne dęcie w rogi baranie, formalistyczną modlitwę, publiczne korzenie się przywódców wspólnoty, symboliczne wygnanie Arki Przymierza i wspólnotowe posty „korygowano” przypominaniem, że przebaczenie uzależnione jest od zmiany niegodziwego postępowania. W tym kontekście przywoływano Prz 28,13 i Lm 3,41 (zob. TB Rosz Haszana 16A, B). Talmud przekazuje napomnienie skierowane do mieszkańców miasta: „Bracia, ani włosiennice, ani posty nie mają znaczenia, tylko skrucha i dobre uczynki. Zobaczcie, że o mieszkańcach Niniwy Pismo nie mówi: Bóg zaś wejrzał na ich włosiennice i posty, lecz mówi: Bóg zaś wejrzał na ich uczynki, iż odwrócili się od złego postępowania (Jon 3,10)". Po wygłoszeniu tego wezwania dodawano sześć specjalnych błogosławieństw: „Swe wystąpienie kończył szóstym błogosławieństwem: «Ten, który odpowiedział Jonaszowi we wnętrznościach ryby, niechaj i wam odpowie i jeszcze dzisiaj wysłucha głosu waszego błagania. Błogosławiony jesteś, Panie, który odpowiadasz w czasie utrapienia»" (Miszna, Joma VIII, 1).

10 E. Levine, The Aramaic Version of Jonah, s. 8.

11 The Mishnah, tłum. H. Danby, Oxford 1933; zob. także: The Mishnah: A New Translation, tłum. J. Neusner, Yale University 1988. 
Z czasem rytuał dnia postu przekształcił się w synagogalną liturgię Dnia Przebłagania. Przestrzegając biblijnego nakazu Kpł 23,27, korzystano z dawnego przepisu: „W Dniu Przebłagania zabrania się jedzenia, picia, mycia się, namaszczania, ubierania sandałów i odbywania stosunków seksualnych". Odprawiano liturgię Minhah, podczas której w całości odczytywano Jonasza, deklamację uzupełniając recytacją trzech wierszy z Mi (7,18-20), które opisują Boże miłosierdzie ${ }^{12}$. Obrzędy Dnia Przebłagania, podobnie jak palestyńskich dni postu, podkreślały zatem przewodnie idee Jonasza: Bóg jest Panem wszystkich ludzi; nie da się uciec przed Jego obecnością; On lituje się nad swymi stworzeniami i udziela przebaczenia tym, którzy zwracają się ku Niemu w prawdzie.

\section{Targum Jonasza w liturgii synagogalnej}

W liturgii synagogalnej zasada - „Prawo wymaga objaśnienia wszystkim zebranym, tak mężczyznom, jak i dzieciom", dotyczyła w równiej mierze Pięcioksięgu, jak i Proroków (Masseket Soferim 18,8). Aramejska wersja Jonasza była zatem odczytywana przez targumistę lub meturgemana, który był odpowiedzialny przed soferem, urzędnikiem wspólnoty, który czuwał nad edukacją publiczną ${ }^{13}$. Kiedy w Yom Kippur sprawowano liturgię Minhah, aramejską wersję Jonasza recytowano co trzy wersy tekstu hebrajskiego ${ }^{14}$. Deklamacja była obwarowana przepisami, które z jednej strony stały na straży prawidłowego tłumaczenia Pisma, a z drugiej zapobiegały powstawaniu wrażenia, jakoby wersja aramejska cieszyła się takim samym autorytetem i świętością jak sama Biblia hebrajska ${ }^{15}$.

12 Początki liturgicznej praktyki dodawania do czytania z Pięcioksięgu czytania z Proroków (haftara) wskazuje się na I w. po Chr. Pierwotnie wybór czytania pozostawał w gestii samego lektora, kierującego się pewnymi konceptualnymi i semantycznymi podobieństwami tekstu do czytania z Pięcioksięgu, jednak pod koniec II w. sfinalizowano tworzenie lekcjonarzy. W późniejszych wiekach powstał zwyczaj błogosławieństw do liturgicznego odczytywania Proroków, co stanowiło ostatni etap kształtowania się tej praktyki. Tamże, s. 9. Zob. też W. Chrostowski, Natura i geneza zjawiska targumizmu, PP 4 (1988), s. 83; por. tenże, Ewolucja sensu Tekstu Świętego na przykładzie targumicznej wersji Ez 16, CTh 61 (1991), s. 63-80; S. Mędala, Wprowadzenie do literatury międzytestamentalnej, Kraków 1994, s. $370-378$.

13 Publiczne odczytywanie targumu uważano za obowiązek religijny i praktykowano go jeszcze przez długi czas po spisaniu danego dokumentu, a nawet po tym, jak aramejski został zastąpiony przez arabski. W. Bacher, Targum, w: The Jewish Encyclopedia 12, red. C. Adler and I. Singer, New York-London 1903, s. 57-63. Zob. też http://www.jewishencyclopedia.com/ view.jsp? artid=67\&letter $=\mathrm{T}$, dostęp 20.05.2009.

14 E. Levine, The Aramaic Version of Jonah, s. 11.

15 Por. W. Smelik, The Rabbinic Reception of Early Bible Translations as Holy Writings and Oral Torah, JAB 1 (1999), s. 249-272. W. Smelik (tamże, s. 249) podkreśla jednak, że: „Rabinackie poglądy na temat przekładów biblijnych różnią się od siebie, zależnie 
Mimo funkcji dydaktycznej i pewnego elementu świętości targumu nie uważano za tekst sakralny i skrupulatnie pilnowano rozróżniania jednego od drugiego. Odczytującemu wersję hebrajską nie wolno było np. popędzać meturgemana, temu z kolei nie wolno było przedkładać tekstu bezpośrednio z wersji spisanej, trzeba było również strzec się, by nie powstawało wrażenie, że oto prezentowany jest tekst kanoniczny ${ }^{16}$. Podobnie jak hebrajski tekst Jonasza, wersję aramejską miał przedstawiać najlepiej dorosły mężczyzna, po którym można było się spodziewać, iż dołoży wszelkich starań, by zebranych nie wprowadzić w błąd albo przez dosłowność przekładu, co zniekształcałoby sens Pisma, albo przez swobodną parafrazę, która zakrawałaby na bluźnierstwo ${ }^{17}$.

\section{Egzegeza żydowska w Targumie Jonasza}

Aramejską wersję Księgi Jonasza cechuje użycie metafor. Świat parafrazy biblijnej zasadzał się na zwykłych przedmiotach i codziennych doświadczeniach, w dużej mierze wynikał z troski, aby słuchacza nie wprowadzać w błąd. Targumiście nie chodziło o to, by po prostu przedstawić zrozumiałą kopię tekstu hebrajskiego, lecz chciał oddać go w formie bardziej zaktualizowanej, akceptowalnej, a nawet polemicznej ${ }^{18}$. W. Smelik ${ }^{19}$ zwrócił uwagę, że w Targumie Jonatana do Proroków można zauważyć obecność przekładu i komentarza, w którym elementy dodane współgrają z wyrażeniami zastępczymi. Podobnie aramejska wersja Jonasza świadczy o tym, że od targumu oczekiwano pogodzenia obu funkcji: translacyjnej i interpretacyjnej.

$\mathrm{W}$ tym celu do przekładu wplatano midrasz lub aluzje midraszowe $\mathrm{w}$ formie niezwykle zwięzłej i sugestywnej, tak aby czytanie odbywało się w sposób nieprzerwany, a słuchacz nie był $\mathrm{w}$ stanie rozpoznać, kiedy ma do czynienia $\mathrm{z}$ bezpośrednim przekładem, a kiedy z midraszem. Oprócz samego tłumaczenia i omówień metodologicznych Targum Jonatana porusza zagadnienia doktrynalne i tekstualne, konkretyzuje sprawy abstrakcyjne, wprowadza upiększenia, budzi

od pochodzenia rabinów i od tego, kiedy żyli. Owe rozbieżności można tłumaczyć sprzeciwem, jaki wobec przekładów podnieśli niektórzy rabini palestyńscy, rabinackim programem mającym na celu ustanowienie Targumów jako ustnej Tory, jak również standaryzacją aramejskich przekładów w Babilonii. W obecnym artykule zajmę się drugą kwestią, mianowicie: kiedy, jak i dlaczego rabini promowali Targumy jako ustną Torę".

16 TB Megilla 32 A. E. Levine, The Aramaic Version of Jonah, s. 11.

17 W. Bacher, dz. cyt., s. 57.

18 Por. np. R. Loewe, Apologetic Motifs In Targum to the Song of Songs, w: A. Altmann, Biblical Motifs, Cambridge 1962, s. 159-196.

19 W. Smelik, Translation and Commentary in One: The Interplay of Pluses and Substitutions in the Targum of the Prophets, JSJ 29 (1998), s. 245-260. 
wiarę w Boską opatrzność, akcentuje skuteczność modlitwy, a nawet wdaje się w polemikęe .

Zdaniem E. Levine ${ }^{21}$, dokładna analiza aramejskiej wersji Jonatana dowodzi, że tekst ten sam w sobie jest jakimś dawnym midraszem, posługującym się parafrazą, dokonującym subtelnych zmian syntaktycznych i stylistycznych, wreszcie nawiązującym do jakiegoś dobrze znanego midraszu o Jonaszu. Wśród ideologicznych elementów targumu można wskazać trzy kwestie: 1) odparcie chrześcijańskiej typologii i apologetyki, 2) wyrażenie ducha i terminologii kultu odprawianego w Jom Kippur, 3) przedstawianie atrybutów Boga i wzmianki o Jego materialności.

\subsection{Aspekt polemiczny}

Pierwotne chrześcijaństwo posługiwało się Księgą Jonasza jako tekstem potwierdzającym eschatologiczną prawdę o zmartwychwstaniu. Świadczy o tym nie tylko sam Nowy Testament (Mt 12,40n; Łk 11,29-32) 22 $^{22}$ ale także pisma Ojców Kościoła $^{23}$. W dokumentach pierwszych pięciu wieków po Chrystusie często natrafiamy na Księgę Jonasza, wykorzystywaną jako tekst apologetyczny dowodzący przekonań eschatologicznych, opracowany metodą typologiczną, zgodnie z którą wydarzenia Starego Testamentu zapowiadały i stanowiły prefigurację tego, co stało się w Nowym Testamencie ${ }^{24}$.

Levine ${ }^{25}$ zwraca uwagę, że Targum Jonasza skrupulatnie unika midraszu, który kładzie nacisk na cudowne oswobodzenie, a który mógłby świadczyć na korzyść egzegezy chrześcijańskiej, zgodnie z którą Jonasz miałby być prekursorem Jezusa. Element polemiczny Levine widzi w 1,9, w którym Jonasz mówi o sobie, że jest Hebrajczykiem (עִברִי אָנדי), co zostaje w tekście targumu oddane jako

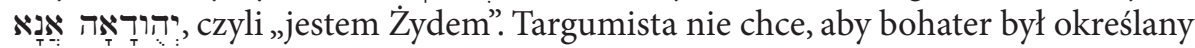
jako Hebrajczyk, bo mogło się to wiązać z duchowym dziedzictwem, do którego również Kościół rościł sobie pretensje. Oprócz tego element polemiczny Levine widzi także w 3 rozdziale targumu. Kiedy to Niniwici okazują się dać wiarę Memra Jhwh, czyli posłannictwu przyniesionemu przez Jonasza, a nie Bogu

20 Por. G. Bissoli, La Bibbia in Aramaico. Verso una mutual definizione di Gudaismo e Cristianesimo, LA 50 (2000), s. 167-180.

21 E. Levine, The Aramaic Version of Jonah, s. 12.

22 R.A. Edwards, The Sign of Jonah in the Theology of the Evangelists and $Q$, London 1971.

23 Np. Klemens Rzymski, List do Koryntian, 7; Tertulian, Adv. Marc. 2,17; 5,4; św. Jan Chryzostom, Ep. 1.15. Za Mt 12,38-41, św. Justyn Męczennik, Dialog z Żydem Tryfonem, 107-108; św. Augutyn, De civ. Dei 18,44. Także św. Cyryl Jerozolimski, który ukazuje paralele między życiem Jonasza i Jezusa w Katechezy 14,17-20.

24 Zob. np. T. Brzegowy, Prorocy Izraela. Cz. II, Tarnów 1994, s. 96-100.

25 E. Levine, The Aramaic Version of Jonah, s. 13. 


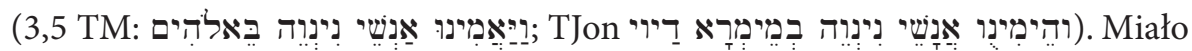
to kwestionować roszczenia chrześcijan w sprawach dotyczących nawrócenia religijnego i wiary. Poza tym ocalenie mieszkańców Niniwy zostaje przypisane zmianie ich postępowania $(3,8 \mathrm{n})$, a nie wierze religijnej.

TM:

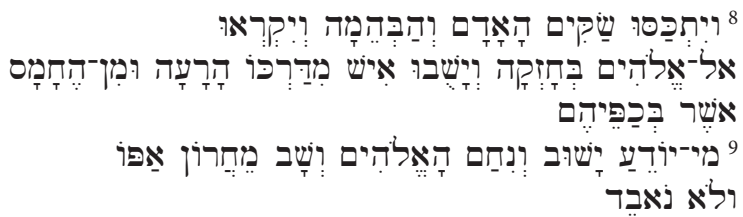

TJon:

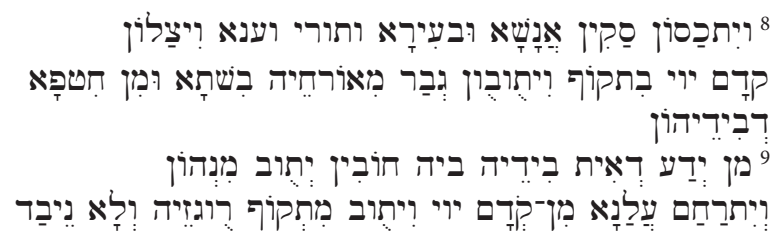

${ }^{8}$ Niech obloką się w wory - człowiek i zwierzę - i niech mocno modla się przed Jhwh. Niech każdy odwróci się od złej drogi i od prze-

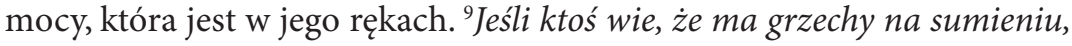
niech za nie żałuje, a zostanie nam darowane przed Panem i odwróci się od zemsty swego gniewu, a nie zginiemy.

W TM 3,9: „Kto wie, może Bóg się odwróci i ulituje?”26 zostaje przepracowane. Targumista podkreśla wyraźnie skuteczność skruchy i nawrócenia, a jednocześnie usuwa $z$ obu wierszy domniemanie, jakoby Bóg czegoś „żałował”. W. 3,9 zawiera zwięzłe streszczenie stanowiska Żydów w sprawie ocalenia: można je uzyskać dzięki uczynkom, a nie przez wiarę.

Stosunek tego Targumu do apologetyki wczesnopatrystycznej ${ }^{27}$ najlepiej, według Levine, widać w 4,5: Jonasz zatrzymuje się, bo chce zobaczyć, jak "na końcu”

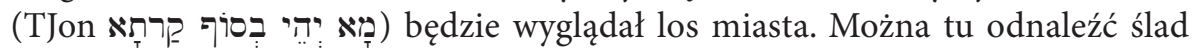
tradycji obecnej gdzie indziej w Targumie Jonatana (Na 1,1), mówiącej o tym, że skrucha Niniwitów była nieszczera i tymczasowa, tak że „na końcu” powrócili do swego grzesznego postępowania - dlatego zostali wyniszczeni ${ }^{28}$. Żydowskie

26 Por Jl 2,14.

27 Ojcowie Kościoła podjęli i rozwijali, polemicznie akcentując antyżydowski aspekt motywu nawrócenia Niniwitów, skrucha mieszkańców Niniwy była ukazywana jako bardziej szczera niż nawrócenie Izraela, do którego prorocy wielokrotnie wzywali nadaremno.

28 E. Levine, The Aramaic Version of Jonah, s. 14. 
teksty z Palestyny z II w. po Chr. i późniejsze mają zupełnie inny charakter, jeśli chodzi o ich podejście do Niniwitów - doszło do przepracowania dawniejszych homilii, bo właśnie na terenie Palestyny i Syrii rozgorzał konflikt chrześcijańsko-żydowski. Oto żydowskie teksty z Babilonii w żadnym fragmencie nie uwłaczają Niniwitom ani ich nie deprecjonują, bo w pierwszych wiekach po Chr. polemiki chrześcijańsko-żydowskie nie odgrywały tam większej roli. Zatem midraszowe nawiązanie w Tg $(4,5)$ ma pochodzenie palestyńskie i datuje się na II-III w. po $\mathrm{Chr}^{29}$

\subsection{Apekt liturgiczny - Jom Kippur}

W Targumie Jonasza zostaje jeszcze wyraźniej uzasadnione stosowanie tej księgi podczas liturgii Dnia Przebłagania. Targumista stawia sobie za cel podkreślenie skuteczności modlitwy, ukazanie tego aspektu nawrócenia, który wiązał się z postępowaniem i uczynkami, zaakcentowanie wiary w odwzajemnianie przez Boga takiej postawy, jaką okazuje Mu człowiek.

Podobnie jak $\mathrm{w}$ innych targumach modlitwa zajmuje tu istotną rolę ${ }^{30}$. Już w tekście hebrajskim jej znaczenie jest bardzo wyeksponowane, targum podkreśla to jeszcze bardziej, używając określonych terminów (np. 1,6 TM: קרָּא

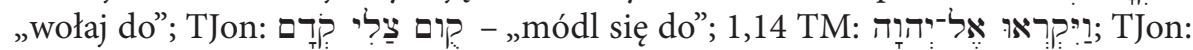

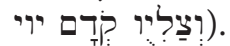

Jonasz w godzinie próby wspomina na „cześć oddawaną Panu” $(2,8)$. Tam, gdzie TM mówi o składaniu ofiary wraz dziękczynieniem, wypełnieniu ślubów oraz akcentuje, że „Wyzwolenie/zbawienie jest u [od] Pana” (2,10b ישוּעָתתה לַיהוֹה targum tłumaczy ten fragment: „wyzwolenie/zbawienie mego życia następuje

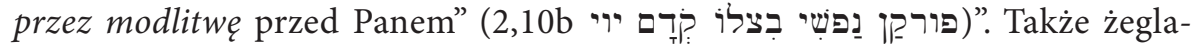
rze uświadamiają sobie, że ich bóstwa nie przyjdą im na pomoc, choć wzywali je na ratunek $(1,5)$, dlatego sami zdają się na Boże miłosierdzie $(1,6)$. Po całym tekście są rozrzucone terminy mówiące o modlitwie, skrusze i nawróceniu, wymowna jest również ich częstotliwość. Boże miłosierdzie i łaskawość ukazane zostają jako rzeczywistość znana nie tylko Jonaszowi, ale także żeglarzom $(1,6.14)$ i samym mieszkańcom Niniwy $(3,9)$.

\section{Tamże.}

30 E. Levine, The Aramaic Version of the Bible. Contents and Context, Berlin 1988, s. 131-134. Rozwój tradycji żydowskiej sprawił, że wzmianki na temat modlitwy w targumach nie tylko są częstsze niż w tekście biblijnym, ale ponadto są wyrażane za pomocą specyficznych terminów. Według A. Shinana, w targumach Pięcioksięgu można odnaleźć około 220 wersów, które odnoszą się do modlitw lub też do modlących się osób. A. Shinan, The Aggada in the Aramaic Targums, Jerusalem 1979, s. 328. Tradycja rabinacka wymienia 13 określeń Biblii hebrajskiej, które uważano za synonimy modlitwy. W tej kwestii targumy zgadzają się w zasadzie z tradycją rabinacką, dokonując przekładu wskazanych wyrazów oraz jeszcze innych i odnosząc je do modlitwy. M. McNamara, dz. cyt., s. 183. 
W Targumie Jonasza zostały wprowadzone także inne zmiany tekstualne mające związek z przewodnim tematem pełnym ufności okazywania czci Bogu. Kult Pana winno się sprawować tylko w stosownym miejscu, dlatego pogańscy żeglarze co najwyżej obiecują złożyć ofiarę Panu, a nie składają jej na pokładzie

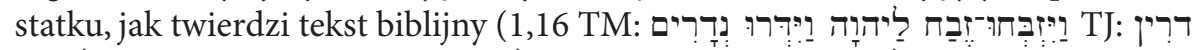

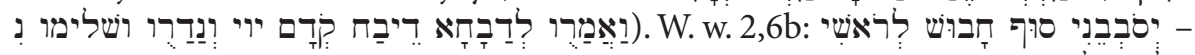

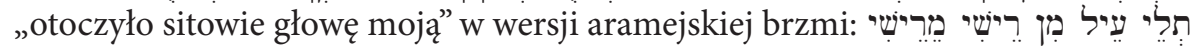

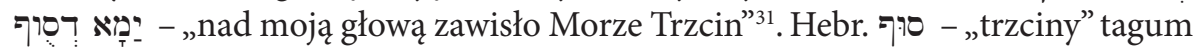
utożsamia z Morzem Trzcin - Morzem Czerwonym. L. Smolar i M. Aberbach ${ }^{32}$ uważają, że wersja targumu stanowiła podstawę midraszu w Pirke de Rabi Eliezer 10, który opowiada o tym, jak Bóg ukazał Jonaszowi drogę, jaką Izraelici przeszli przez M. Czerwone. Zdaniem Levine, stanowi to midraszowe nawiązanie do podwodnej podróży Jonasza, podczas której zostaje on pouczony m.in. o tym, jak oddawać Bogu cześć, stojąc przed Jego tronem ${ }^{33}$.

\subsection{Aspekt doktrynalny}

Poza nielicznymi wyjątkami (takimi jak: $\mathrm{Tg} P s, \mathrm{Tg} K o h$ ) pierwszorzędnym celem znanych nam targumów było - jak się wydaje - „przekazanie sensu, tak aby lud rozumiał czytanie", by wyrazić to słowami $\mathrm{Ne} 8,8^{34}$. Oryginalny tekst hebrajski miał być przetłumaczony zwykłym słuchaczom w sposób, który nie stałby w sprzeczności z obowiązującymi koncepcjami religijnymi, w związku z tym zwroty i fragmenty Jonasza odnoszące się do Boga zostają raczej sparafrazowane niż dokładnie przetłumaczone. Teksty antropomorficzne i antropopatyczne są zamienione na inne, z obawy, żeby nie wywołały w umysłach słuchających koncepcji prymitywnych lub niezgodnych $\mathrm{z}$ doktryną ${ }^{35}$. W wersji hebrajskiej Jonasza imiona Boże często występują z towarzyszeniem dopełnień i przyimków, względnie jako podmioty czasowników, np. wzmianki o „Bożym słowie” $(1,1$; 3,1.3), „Bożej obecności” $(1,3 ; 2,7)$, Bożych oczach $(2,5)$ i emocjach $(4,2)$.

Dla wyeliminowania skojarzeń cielesnych i antropomorficznych, które mogłyby powstać wskutek dosłownego przekładu wersji hebrajskiej, targumista posługuje się kilkoma instrumentami. Wstawia np. pełniące funkcję pośredniczącą

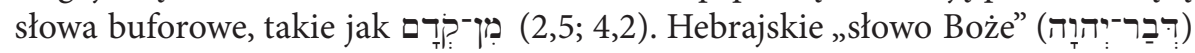

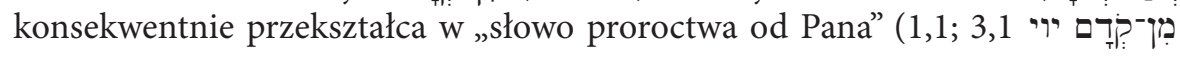

31 Por. K.J. Cathcart, R.P. Gordon, The Targum of the Minor Prophets, AB 14, Edinburgh 1989, s. 107.

32 L. Smolar, M. Aberbach, Studies in Targum Jonathan to the Prophets, New York 1983, s. 123.

33 E. Levine, The Aramaic Version of Jonah, s. 15.

34 M. McNamara, dz. cyt., s. 171.

35 Tamże, s. 175. Por. P.S. Alexander, Jewish Aramaic Translations of Hebrew Scriptures, s. 226. 


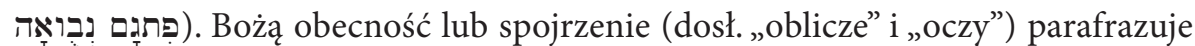

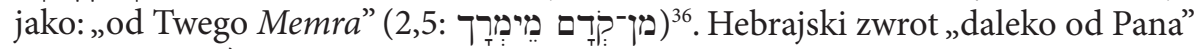

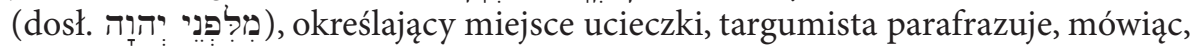

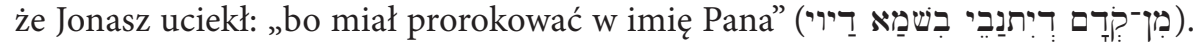
Nawet wzmianka o tym, że Jonasz przypomniał sobie o Bogu, zostaje zamieniona na jego wspomnienie o „czci oddawanej Bogu” $(2,8)$. W miejsce tekstu o Bogu, który „żałuje zła” $(4,2)$, w targumie jest o tym, że On „odwołał swoje Memra

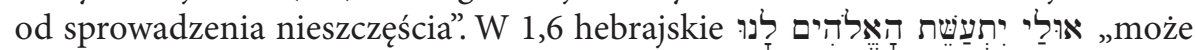

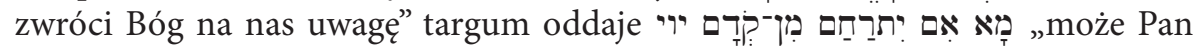
okaże nam miłosierdzie". Targumista nie zastosował przekładu literalnego, ponieważ nie chciał, by powstało wrażenie, że Bóg mógłby zmienić zdanie ${ }^{37}$.

W wielu miejscach (zob. 1,6.9.14.16; 2,2.3.5.10; 3,1.3.6.10; 4,2) targumista stosuje określony typ parafrazy związany z użyciem przyimków. Tam, gdzie $\mathrm{w}$ wersji hebrajskiej pojawia się przyimek przypisany do imienia Bożego, przekład aramejski stosuje jego oddzielenie: „do" (אל) zastąpione zostaje "przed” (קדם), natomiast „od” (מן) staje się „sprzed” (מן קדם).

W targumach prócz tendencji przeciwnej antropomorfizmom unika się stawiania Boga w bezpośrednim podmiocie lub dopełnieniu jakiegoś działania. Zamiast Boga są one wykonywane raczej „przed Panem”, względnie spełniają je Boże Memra, Jego Chwała, Obecność lub Szekina ${ }^{38}$.

Przykłady tego typu tłumaczenia występują również w Targumie Jonasza. W tekście hebrajskim tam, gdzie imię Boże pojawia się w zdaniu jako dopełnie-

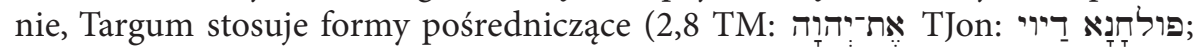

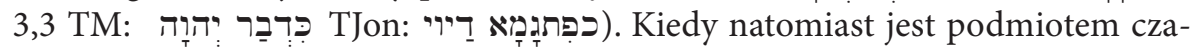
sownika lub imiesłowu, targum stawia je w rzeczowniku poprzedzonym przy-

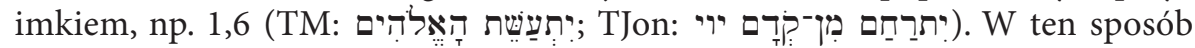
targumista usuwa wyraźną wzmiankę o Bogu jako aktywnym podmiocie działającym w danej sytuacjii ${ }^{39}$.

Wersja aramejska za pomocą zmian gramatycznych, parafrazy lub uzupełnień systematycznie przeredagowała tekst hebrajski, eliminując lub modyfikując materialne i antropomorficzne wzmianki o Bogu oraz takie Jego prezentacje, które nie były zgodne z religijnymi koncepcjami translatorów.

36 „Memra (Pańskie)” to wyraz w targumach jeden z najbardziej charakterystycznych, którego nie poświadczają inne źródła żydowskie. Wywodzi się z rdzenia ' $m r$ - „mówić" i najogólniej oznacza „słowo”. Sporadycznie, choć rzadko, przyjmuje znaczenie „nakazać”. M. McNamara, dz. cyt., s. 178.

37 K.J. Cathcart, R.P. Gordon, dz. cyt., s. 106.

38 M. McNamara, dz. cyt., s. 178.

39 E. Levine, The Aramaic Version of Jonah, s. 16. 
W hebrajskiej Księdze Jonasza pojawiają się dwa imiona Boga: JHWH oraz Elohim ${ }^{40}$. W rozdz. 1-3 imię Jahwe jest używane przez autora hebrajskiego lub Jonasza, natomiast Elohim przez pogan lub w odniesieniu do nich. Jednak podział ten nie sprawdza się w rozdz. 4, bo oba imiona są używane zamiennie i bez rozróżniania. W tekście aramejskim JHWH - 35 razy, Elohim - 7 razy. Rozbieżność ta wynika przede wszystkim stąd, że zawarte w Biblii hebrajskiej „Elohim” w targumie zostaje zastąpione świętym tetragrammatonem (3,3.5.8.10; $4,2.7 .8 .9)^{41}$.

Targum Jonasza, podobnie jak inne istniejące teksty targumiczne, jest świadkiem tej wersji Biblii, której wspólnota wysłuchiwała i którą gromadziła przez wieki, musiała zatem przechodzić ewolucję literacką i lingwistyczną. Dzięki tym tekstom dysponujemy materiałem źródłowym, który umożliwia badania nad filologią semicką i egzegezą biblijną. Analiza wersji aramejskiej Księgi Jonasza ukazuje, że obok zagadnień tekstualnych i doktrynalnych podkreśla on miejsce tej księgi w liturgicznej tradycji żydowskiej. Może także przedstawiać pewne elementy polemiki z chrześcijaństwem. Polemika ta jest mocno stonowana. Wychwytuje się ją tylko wtedy, gdy porównuje się interpretację biblijną targumu z odmienną, podawaną przez literaturę chrześcijańską.

\section{The aramaic version of Jonah}

\section{Abstract}

Aramaic version of Jonah like another Targums testifies, the targum was expected to reconcile the two functions of translation and interpretation. Extant targum texts witness to a Bible version that was heard and assimilated by the populace during centuries of literary and linguistic evolution. For the Targum of Jonah assumes the authorship of a meturgeman or targumist who composed this targum for performance in the synagogue on Yom Kippur, for a community that would supposedly be able to understand all the implicit references to various rabbinic traditions. In the Targum of Jonah reflect the influence of jewish Ideology concerns of three aspects: 1) polemical with Christian exegesis; 2) liturgical Yom Kippur worhisp; 3) doctrinal - attribute of God.

40 Hebrajski tekst imię własne JHWH podaje 26 razy, a Elohim w jego rozmaitych formach 16 razy.

41 E. Levine, The Aramaic Version of Jonah, s. 17. 
